\section{Город- гиперобъект. Введение}

\section{Александр Вилейкис, Полина Ханова}

\section{Первый город. Первый убийца}

Кто построил первый город? Каин. Герой иудеохристианской мифологии, первый убийца, обреченный Богом на вечную жизнь и покинувший Эдем, построил первый город в земле Нод. Некоторые комментаторы Писания усматривают в истории Каина и Авеля не историю о братоубийстве и божественном наказании, а иллюстрацию перехода от кочевого к городскому образу жизни, где библейские герои выступают исключительно в качестве удобных метафор.

Что произошло с Каином, Авелем и первым городом?

Земледелие буквально является «письмом» по телу Земли. Неолитическая аграрная революция, возможно, первая точка отсчета антропоцена'. Пока люди сохраняли исключительно кочевой образ жизни, пространство не наделялось полярностью. Окружающая среда оставалась гомогенной, почва не разделялась на плодородную и скудную, первые стоянки и пещеры не образовывали дом² в полном смысле этого слова, а территория не разделялась на свою и чужую.

Аграрная революция стала первым «осмыслением» территории, создав первую значимую точку, место для перспективы, исходя из которого ранее кочевые люди могли выстраивать собственные отношения с другими объектами в пространстве. Появление первого «жилища», способного полноценно обеспечить население пропитанием, стало началом производства территории - появления первобытной топологии, первой точки, из которой развертываются оси координат.

1. Геологическая эпоха, в которую начинается необратимое влияние человека на планету. Ученые не определились с датой начала антропоцена, среди гипотетических вариантов называют переход от кочевого образа жизни к оседлому, промышленную революцию, первые ядерные испытания. Подробнее об этом см.: [Мортон, 2019]

2. О доме здесь говорится в значении, разработанном Гастоном Башляром [Башляр, 2014] и впоследствии развитом Анри Лефевром [Лефевр, 2017], а также другими наследниками этой традиции. Жилище понимается как первый способ освоения окружающего пространства, посредством которого человек впоследствии исследует окружающий мир. Можно говорить об определенном сходстве с понятием первичной социализации в социологии [Бергер, Лукман, 1995], но, в отличие от социальной теории, для Башляра и Лефевра дом выступает не только в качестве системы различений, сети координат или набора базовых метафор, но и фактически формирует образ мышления, применяемый впоследствии к любому другому феноменальному опыту. Важно, что кроме способности познавать и разделять, дом как у Башляра, так и у Лефевра обладает «темными местами»- это подвал и чердак, через которые в повседневную реальность может проникнуть нечто «жуткое» (unheimlich) [Фрейд, 1995]
Вилейкис Александр, основатель Центра новой философии (ЦНФ, Москва); сотрудник Института социально-гуманитарных наук Тюменского государственного университета (ТюмГу); Российская Федерация, 625003, Тюмень, ул. Ленина, 23. E-mail: alexandro.vileykis@gmail.com Ханова Полина, ассистентка кафедры онтологии и теории познания философского факультета Московского государственного университета имени М.В. Ломоносова (МГУ); Российская Федерация, 119991, Москва, Ломоносовский пр-т, 27, корп. 4.

E-mail: linakhanova@gmail.com

В статье предлагается переосмысление города при помощи концепта гиперобъекта, созданного Тимоти Мортоном. Прослеживая эволюцию отношений между городской средой и жителями, авторы предлагают воспринимать город в качестве устойчивого объекта, внешнего по отношению к населению и обладающего характеристиками гиперобъекта. Такой подход позволяет объяснить, почему восприятие окружающей среды у сельских и городских жителей разнится столь сильно и как устроена ситуация «поломки» нормальной городской повседневности, приводящая к формированию новых тревог, страхов и разных форм ужаса. Отправной точкой авторской интерпретации является прочтение иудеохристианского мифа об Авеле и Каине как описания перехода от животноводства к земледелию и, следовательно, зарождения городского образа жизни. Обсуждая разные способы интерпретировать миф, авторы обнаруживают ключевые различия между существованием в городской среде и деревенским образом жизни-лакуны пространства, вытесняемые населением на задний план. Такая многослойность перспективы характерна исключительно для городского образа жизни. Изучая особенности восприятия, исследователи показывают, как подобные изменения в повседневности стали следствием существования в тени города-гиперобъекта, который является чем-то большим, чем место жительства.

Ключевые слова: город; городская повседневность; миф; повседневная магия; мифологическое сознание; Джон Ло; Тимоти Мортон; ситуативные знания; городские исследования; урбанистика; антропоцен; гиперобъект; темная экология

Цитирование: Вилейкис А., Ханова П. (2021) Город-гиперобъект. Введение//Городские исследования и практики. Т. 6. № 4. С. 7-16. DOI: https:// doi.org/10.17323/usp6420217-16 
Кочевники носят с собой свой центр мира, перестраивая его в соответствии со временем года, природными условиями, поведением животных и растений и множеством других факторов. Дом вбивает в материальную топологию гвоздь, на котором держится культурная вселенная. Отныне не центр мира следует за территорией, а территория перестраивается в соответствии с человеческим миром и его отношениями центр-периферия, свое-чужое. Окультуривание растений, освоение почвы и, как следствие, формирование одомашненного пространства позволили провести границу между природой и культурой, между домом и окружающей средой, тем самым сделав первый шаг к рождению городской среды.

Почему именно Каин строит первый город? Дело не только в том, что он является землепашцем, но и в первом убийстве, первом преступлении и «каиновой печати». Как гласят некоторые варианты истории о братоубийстве, Каин обвиняется не в убийстве Авеля, но в попытке солгать Богу о преступлении (отвечая, что не знает, где на самом деле находится Авель) или выдать мотивированное убийство (предполагается, что Каин завидовал Авелю и питал к нему ненависть) за акт жертвоприношения. Появляется преступление и различие между истиной [Фуко, 2016] и повседневной практикой. Бог, выступая в качестве суверена, говорит от лица истины, становясь не только источником правосудия, но проводя различие между устойчивым законом и практиками, основанными на реципрокном доверии. Каин виновен, потому что его сделала виновным власть, обладающая возможностью говорить от лица истины, а не потому, что наказали другие члены сообщества.

Последний элемент истории - «каинова печать», которой, согласно некоторым версиям мифа, Бог «награждает» первого преступника. Маркировка человека ${ }^{3}$ является симптомом городской среды, где высокая степень неопределенности и отсутствие плотных социальных связей вынуждают создавать инструмент для упорядочивания социальной реальности путем обозначения людей как представителей определенной категории [Зиммель, 2002].
Город является не просто другим местом жизни, но и причиной зарождения иной картины мира, которая принципиально отличается от сельского сообщества, поскольку предполагает плотную границу между природой и культурой, обозначаемую допотопным частоколом. Город мог быть основан таким образом, а мог-любым иным. Иудеохристианский миф лишь обнажает важные символические черты городской среды, которые выдают в ней рукотворный гиперобъект.

\section{Рукотворный гиперобъект}

Итак, первый город основал Каин, убив своего брата Авеля и солгав Богу о мотивах своих действий. Так появились посредники между людьми, определяющими их действия. Так начался антропоцен.

Городская среда, предельно усложнив существование сообществ, изменила образ мышления, проведя границу между природой и культурой, породив одновременно иллюзию контроля социальной реальности и городское бессознательное, готовое разорвать привычную ткань повседневности и дестабилизировать социальные практики, поместив человека в ситуацию турбулентности. Человечеству удалось создать рукотворный гиперобъект, но в силу размера этого гиперобъекта ему никогда не удастся его контролировать.

Но что бы это могло вообще значить рукотворный гиперобъект? Не парадокс ли это? Похожий парадокс возникает у Тимоти Мортона, когда он пытается работать с глобальным потеплением как гиперобъектом. Не является ли оно тоже рукотворным гиперобъектом, ведь именно этот феномен представляет собой принципиальный маркер антропоцена (человеческая деятельность становится фактором геологического масштаба), а «рукотворность» глобального потепления - тезис, за признание которого идет основная борьба в поле классической, «светлой» экологии, по отношению к которой Мортон настроен весьма критически. Нет, рассуждая о глобальном потеплении и антропоцене, Мортон смещает дату его начала в прошлое: не до появления паровых двигателей или использования угля, как это уже делали

3. С этим утверждением можно не согласиться, отослав к работе Георга Зиммеля «Эссе о чужаке» [3иммель, 2003, с. 173-178] и последующей антропологической теории, предполагающей маркировку определенных людей в качестве «персонажей» в ситуации сельского сообщества, таких, например, как ведьма, кузнец или бродячий торговец. На это возражение можно ответить тем, что каждый из подобных персонажей вписан в сельский мир через границу, которая проходит либо между деревней и городом (бродячие торговцы, сборщики налогов), либо между обычным и потусторонним миром (кузнец, феи, ведьмы и т. п.). 
до него, а еще глубже-в неолитическую аграрную революцию, когда Homo sapiens перешел от охоты и собирательства к оседлому земледелию, распахивая землю и меняя, таким образом, геологический и атмосферный баланс и создавая новые биологические виды. Это и есть момент рождения того самого разделения на природу и культуру (культура - это распаханная земля) и рождения человека как вида. Антропоцен-современник антропоса, поэтому, с точки зрения Мортона, бесполезно принимать на себя вину за современную экологическую ситуацию, если вина эта не распространяется на человечество как биологический вид. Мы современники антропоцена, и, если бы не он, нас бы не существовало, так что он «рукотворен» ровно в той же степени, в которой «рукотворен» сам Homo sapiens.

Этот парадокс применим и к городу: можно ли сказать, что город изобретается? В какой именно момент мы начинаем считать нечто городом? Когда он достигает определенной численности жителей? Но, скажем, древневавилонский город мог быть меньше иного современного поселка. Создание оседлого поселения достаточных размеров, обнесенного (опционально) стеной, - это еще не сотворение города.

Город - это «устойчивая форма бреда», как метко называет ее Иван Кудряшов, это

прежде всего атмосфера, что связана отнюдь не с непосредственным восприятием, а со специфической реконструкцией опыта. Здесь также центральное место занимает фантазия, которая и придает форму - цельность и осмысленность. Фактически, придать форму своему опыту, полученному от города, это и значит создать ту самую «атмосферность», которая затем не столько фиксирует разрозненные события, запечатленные в памяти, сколько обрамляет их [Кудряшов, 2019].

Человек не живет в городе до тех пор, пока его опыт не примет форму города: «город как раз и производит тех, кто его переживает в опыте и описывает» [Кудряшов, 2019]. В этом смысле он подвержен тому же парадоксу, что и антропоцен Мортона: он порождение воображения, которое само создает воображающего. В этом смысле удобнее описать город как продукт гиперверия.

Неспроста автор этого термина, Ник Ланд, приводит в качестве примера гиперверия именно город: «Трактовка
Иерусалима как священного города с особенной всемирно-исторической судьбой, к примеру, обеспечила культурные и политические инвестиции, сделавшие ее истинной» [Карстенс, Ланд, 2019, c. 262]. Пример характерен: по крайней мере для европейской культуры Иерусалим не просто город с особой судьбой, за который на протяжении трех тысячелетий идет борьба с высокими ставками и сама длительность которой делает его судьбу особой. Это образ города по преимуществу, архетипического прообраза всех городов. Спрашивать, что было прообразом Иерусалима, бесполезно: он сам собственный симулякр, самоисполняющееся пророчество, сбывающееся не только в будущее, но и в прошлое. Таким архетипическим городом-прообразом в разные периоды выступают Афины, Рим, Лондон, Нью-Йорк... Мортоновский гиперобъект par excellence - глобальное потепление - является таковым именно потому, что одновременен своему создателю и входит в петлю положительной обратной связи с человечеством как видом. Точно так же город как гиперобъект и гиперверие входит в петлю положительной обратной связи с тем, что мы называем человеческой культурой. В этом смысле альтернативной стратегией исследования города была бы двойная оптика (точнее, аноптика, так как зачастую часть ее стратегий будет невозможность видеть) - город как гиперверие, устойчивая самовоспроизводящаяся форма мышления, стремящаяся к воплощению, и город как гиперобъект.

Чтобы понять, какие формы и фигуры характеризуют мышление города, можно посмотреть на несколько его характерных мифологем.

\section{Логики бреда}

Во-первых, мифологические описания генезиса городской среды позволяют заметить важный элемент: город-способ мышления об окружающем мире, построенный на логике различений.

В «Различии и повторении» Жиль Делез [Делез, 1998, с. 149-157] описывает образ «темного предшественника» - тьму перед явлением молнии, позволяющую ей быть заметной. Чтобы различение состоялось, должны быть подходящие условия: темнота/молния, пустота/граница. Пока вся окружающая среда воспринимается гомогенной, невозможно ни провести границы, ни испытать horror vacui-ужас пустоты, потому что объекты обладают 
равноправием в глазах наблюдателя

[Вудард, 2016; Woodard, 2013, p. 118].

Границы, в свою очередь, позволяют разделить ранее гомогенную картину мира на несколько категорий, производящих одни объекты в качестве части "территории» ${ }^{4}$, а другие - нет. Часть объектов исключается из освоенного пространства, так как они мешают существованию устойчивой повседневной реальности. Неопределенность, порождаемая неизученными объектами, исключенными из перспективы городского обывателя, вместе с границами, очерчивающими ее визуальные рамки, формирует свой собственный, особый тип восприятия пространства. На смену гомогенному миру, в котором каждый объект присутствует постоянно, приходит новый перспективизм, где есть передний план, населенный значимыми объектами и практиками, и «задний план», перегруженный всяким хламом, - хинтерланд [Ло, 2015]. Увеличение числа нестабильных объектов приводит к появлению посредников, позволяющих сохранять устойчивость повседневной жизни в изменившейся ситуации. Житель городской среды едва ли знает собственных соседей, что вынуждает иметь посредников (например, деньги) [Гребер, 2015] и оставлять в пространстве лакуны, обладающие потенциалом неопределенности.

Что дает подобное избирательное восприятие городского жителя, «блазированность» ${ }^{5}$ его повседневных практик? Разделение окружающей среды на знакомую и неизвестную позволяет провести границу между двумя типами пространства, исключив второй из внимания. Пожалуй, ярче всего этот тип восприятия представлен у Чайны Мьевиля в повести «Город и город»: жители городов-близнецов Бещеля и Уль-Комы, занимающих фактически одно географическое пространство, обладают отточенным навыком не замечать включения другого города в их собственный. Подозрительное, опустошенное - городская изнанка - проявляет себя только в кризисных ситуациях и городской мифологии: жители Бещеля и Уль-Комы рассказывают о городе-побратиме страшные байки, а преступление, совершенное в точке «противоестественного» смешения двух городов, воспринимается почти как сверхъестественное. Но вот граница как таковая вовсе не является для жителей двух городов проблематичной. Фронтир, граница, линия, за которой hic sunt dracones, вытесняется из повседневности обывателей.

Интересно, что логику хинтерланда в той или иной степени воспроизводят классические подходы к урбанистике, как, собственно, и вся наука Нового времени, для описания которой Джон Ло и предложил этот термин:

Я предлагаю понимать их как метод сборки, то есть как реализации отношений, разделяющих вещи на присутствующие «здесь-внутри» (репрезентации, объекты, восприятия) и отсутствующие «там-вовне». У последних есть две формы: явленное отсутствие (к примеру, как то, что репрезентировано) или более проблематичный хинтерланд неопределенной, необходимой, но скрытой Инаковости» [Ло, 2015, 38].

Наука производит свои объекты, очищая их от мутных, неустойчивых, зависимых и ненадежных элементов, тем не менее вовлеченных в их производство.

В XX веке с появлением профессиональных городских исследований теоретическое оформление и производство города как (гипер)объекта было поставлено на поток. Дискурсы о городе сильно отличаются в зависимости от теоретической идеологии, которую принимает тот или иной исследователь. Виктор Вахштайн, например, в одной из своих работ выделяет три такие оптики: «модернистский урбанизм», «левый урбанизм» и то, что он полушутя называет "хипстерским урбанизмом» [Вахштайн, 2014]. Отличаются они прежде всего онтологией, то есть тем, что рассматривается в качестве базового набора объектов, составляющих то, что называется городом. В случае модернистского урбанизма город - это машина: машина роста, машина производства определенного типа людей, форм жизни или отношений. Машина, нацеленная на развитие, рост, прогресс и прочие модернистские идеалы, - это «Лучезарный город», рациональные города Просвеще-

4. Территория используется в значении Анри Лефевра [Лефевр, 2017], подробнее эта тема развита в: [Вилейкис, 2019].

5. Термин Георга Зиммеля [Зиммель, 2002]. Блазированность-избирательное внимание горожанина, сосредоточенное на значимых для него объектах. Социолог видит причины такого поведения в необходимости избегать эмоционального перенапряжения от постоянного чувства нестабильности окружающей среды. 
ния и т.д. Левый урбанизм представляет тот же самый город в первую очередь через людей, их восприятие и отношения. Увиденный в такой оптике, модернистский город-машина предстает инстанцией подавления, контроля, отчуждения, самых разных форм институционализированного и воплощенного в материальных и архитектурных формах неравенства и насилия, с которым нужно каким-то образом бороться. То, что Вахштайн ласково назвал "хипстерским урбанизмом», по-видимому, видит город как экран, как пространство не только наблюдения в фукианском смысле, но и пространство демонстрации, показывания себя, созерцания происходящего и, соответственно, моделирования и производства этих созерцаний; производство сообществ, общественных пространств становится его основным практическим мотивом.

Николай Руденко добавляет к этому списку «киборгианский урбанизм», или «урбанизм ассамбляжей» [Руденко, 2017], который пытается представить город как куда более сложно организованную материальную конструкцию, состоящую из самых разных типов объектов, по-разному подключающихся друг к другу на разных уровнях и с помощью разных интерфейсов. Соответственно, вместо метафоры машины или образа сцены операциональной становится метафора киборга, отсылающая к комбинации биологических и технологических, материальных и идеальных, социальных и технических элементов. Соответственно, меняется вся лексика и концептуальная метафорика, применяемая для описания города. Например, появляется описание дома как сложного техноэкологического модуля, связанного с самыми разными сетями и интерфейсами: системами канализации и водопровода, доставки еды и медицинской экспертизы, политик наблюдения и исключения, обмена информацией и т.д.

Скорее всего, таких идеологий можно найти еще немало. Но всем им предшествует город как нерасчлененное целое, город, остающийся в хинтерланде анализирующих, расчленяющих методик и порождающий субъекта, способного породить эти методики. Для Ло хинтерланд - метафора: то, что остается «на фоне», «за спиной» произведенного научного факта. Для города хинтерланд буквален: это и тыл, и внутренняя сторона, и изнанка, земля, на которой стоит город, его скрытая и неопределенная Инаковость.

\section{Геотравма и хинтерланд}

Изнанка может обнаружиться, когда аналитический инструментарий дает сбой. Когда же ломается сам гиперобъект, демонстрируя наблюдателям свою изнанку, они выпадают из своего повседневного состояния, изменяясь под воздействием оказанного влияния. «Поломки» города приводят к значимым изменениям устройства повседневности, оставляя следы долгосрочного влияния в восприятии горожан. Такие поломки - масштабные природно-технические катастрофы, инфраструктурные коллапсы, вскрывающие изнанку городского.

Один из наиболее известных случаев инфраструктурного коллапса городской среды-ураган «Катрина» в Новом Орлеане. После катастрофы практически весь город был отрезан от инфраструктур США. Территория Нового Орлеана превратилась в своеобразный failed state, где не существовало ни устойчивых правил игры, ни социального порядка [Anand, Gupta, Appel, 2018]. Полицейские, пытавшиеся предотвращать преступления, в какой-то момент начали попросту фотографировать мародеров в надежде, что получится арестовать их когда-нибудь потом. Многие пожарные, как и врачи, перестали реагировать на просьбы о помощи из-за невозможности сделать хоть что-то, так как не работали ни больницы, ни пожарные части, а медикаменты и другие ресурсы быстро закончились. Значительная часть сотрудников государственных служб сами превратились в мародеров и вместе с населением пытались получить сиюминутную прибыль. В затопленном городе стали распространяться болезни, ранее характерные только для «неблагополучных» стран и практически забытые на территории США. Система здравоохранения не была готова к борьбе с ними, так как зачастую врач не мог правильно диагностировать болезнь, предполагая, что пациент поступает из первого мира, а значит, едва ли может болеть чем-то давно «побежденным». Последствия катастрофы привели к значительному росту уровня самоубийств среди сотрудников полиции, пожарной охраны, скорой помощи [Berardi, 2015]. Люди, в обычной ситуации обладающие способностью контролировать порядок и спасать жизни, были совершенно не готовы к ситуации абсолютного бессилия.

Последствиями бедствия стали не только изменения в федеральной политике, когда практика конструирования «монументальной» инфраструктуры начала уступать место логике проектов, гибких по отноше- 
нию к изменяющимся условиям окружающей среды ${ }^{6}$, но и перемены на уровне локальных представлений о городской природе, внезапно ставшей источником потенциальной опасности.

Новый Орлеан является наиболее известным, но далеко не единственным примером смены инфраструктурной политики из-за «поломки» городской среды. Периодические блэкауты, характерные для некоторых американских штатов, являются менее масштабным, но более регулярным бедствием, показывающим создателям крупных инфраструктур возможность города действовать самостоятельно.

Глобальные инфраструктурные кризисы демонстрируют влияние города-гиперобъекта. Когда городская среда перестает быть лишь условием для создателей инфраструктуры, становясь полноценным действующим лицом, актором, от действий которого зависят остальные члены системы. Город переходит из пассивного состояния в активное, даже на теоретическом уровне утрачивает свою предсказуемость, что является определяющим свойством объекта «стабилизированной» картины мира. Неустойчивость города-гиперобъекта размывает различие природы и культуры, но не возвращает жителей в сельскую логику, так как они лишены опыта пребывания в гомогенной среде, не способны адекватно реагировать на радикальные изменения состояния городской среды, что становится причиной волн самоубийств, развития психологических заболеваний, уличного насилия и формирования коллективной травмы на уровне целых городских сообществ.

Концепция коллективной травмы, разработанная Джеффри Александером [Александер, Куракин, 2012] в социальной теории, описывает логику проживания травмы в качестве способа формирования сообщества. Аргумент состоит в том, что пережитые события, одинаковые для большинства членов коллектива, как и последующее погружение в схожий опыт оставшихся незатронутыми первичной травмой, приводит к созданию сообщества на основе солидарности вокруг травматического опыта.

В противовес такой логике Тимоти Мортон пишет о «геотравме», ситуации столкновения человека с разрушением романтического идеала покорной Природы [Мортон, 2019]. Различие между опытом коллективной травмы и геотравмы в том, что первая вписана в привычную картину мира городского жителя, а вторая ставит ее под вопрос, вызывая постоянное ощущение тревоги, которую невозможно купировать ни коллективностью опыта, ни его конечностью.

Коллективная травма в конце концов замыкается, формируя устойчивый нарратив не-повторения печальных событий, ярким примером которого является логика never again, распространившаяся в западном обществе, пережившем Холокост: сообщества объединяются не вокруг пережитого опыта, а через коллективные практики по предотвращению его возвращения [Вилейкис, 2020].

Пережитая геотравма в отличие от коллективной травмы никогда не закрывается полностью, но всегда обладает потенциалом к повторению, потому что причина возникновения этого опыта заключается в явлении наблюдателю нестабильной городской изнанки, которая никуда не исчезает после травматизирующих событий, а просто возвращается на «задний план»в хинтерланд, формируя мрачный горизонт самого городского существования.

Коллективная травма, описываемая Александером, работает на цементирование городского способа мышления, приписывая отдельному индивиду еще большую агентность, в то время как опыт, описываемый Мортоном, демонстрирует зыбкость оснований данной логики, приводя наблюдателя к осознанию постоянной нестабильности собственной повседневности, ежедневно повторяя опыт турбулентности и не предлагая эффективного механизма стабилизации картины мира.

Город построен как геотравма, жить в городе - значит жить на пороховой бочке, в зоне постоянного риска (как бы ни были надежны стены и улицы этого города, для этого вовсе не обязательно жить в сейсмоопасной или подверженной затоплениям зоне): поскольку город - гиперобъект, которым пронизаны мы все, то возможность его «поломки» является необходимой его составной частью. Всякий объект

6. В особенности к аномалиям, ставшим одним из последствий глобального изменения климата. Предшествующая логика создания крупных инфраструктур руководствовалась стремлением учитывать текущий климат, в котором городу предстоит существовать, в качестве константы, в то время как парадигма, приходящая на смену после урагана «Катрина», исходит из возможности резких изменений состояния окружающей среды и не ориентируется исключительно на типичную ситуацию. Такая политика получает наибольшее развитие в арктических городах Аляски, Скандинавских стран и Канады. 
проявляет собственную реальность, когда отказывается полностью подчиняться; город тоже является реальным объектом, и геотравма - симптом его реальности.

\section{Городские ужасы}

Геотравма в городской среде необязательно носит характер масштабного столкновения со стихией, подобно урагану «Катрина» или Лиссабонскому землетрясению.

Подрыв устойчивых оснований городской повседневности может произойти по совершенно локальным причинам и быть заметен в масштабе индивидуального опыта. Город способен действовать как гиперобъект не только в крупном масштабе, но и на уровне локальных повседневных практик, вторгаясь в распорядок жизни городского населения. Мортон называет это свойство гиперобъектов «липкостью»:

Растворяется не реальность - растворяется субъект, сама способность «отражать» вещи, существовать отдельно от мира в качестве кого-то, кто смотрит на отражение в зеркале, будучи удаленным от него благодаря онтологической оболочке из отражающего стекла... Объекты суть то, что они суть, - в том смысле, что вне зависимости от нашего знания и способа его приобретения объекты [существуют] здесь, и от них невозможно отделаться [Мортон, 2019].

Например, опыт сталкинга в большинстве случаев ставит под подозрение всю городскую среду. Жертва, столкнувшаяся с преследованием, не может быть до конца уверена в неповторении подобных событий, в особенности когда преследователь остается на свободе. Сам по себе город становится источником опасности, так как привычная логика освоенной территории безопасного «переднего плана» городской среды-оказывается нарушенной, выпуская наружу подозрительную изнанку. Пространство перестает быть нейтральным, так как в любой момент опасность может вернуться в иной форме.

Город-зеркало разума, цивилизации и человеческого как такового, и зеркало города плавится и прилипает к рукам, поэтому классическая логика оптического, логика «выведения на передний план», «высвечивания» и в конечном итоге Просвещения отказывает при встрече с городской изнанкой - поскольку такова материальность самого зеркала, которую никак не получается отразить.
Поэтому исследователи города как гиперобъекта прибегают либо к литературному опыту, либо к особого рода психогеографии (как это делает, например, Ник Данн в «Манифесте ночного города», публикуемом в данном номере). Ситуационистская психогеография, впрочем, видела свою задачу в противостоянии городскому "спектаклю», реализующему политические структуры подавления, то есть в конечном итоге тоже представляла город через призму эмоций и поведения людей. То, как ходят по ночному городу Вирджиния Вульф, Чарльз Диккенс и - уже более целенаправленно - Ник Данн, имеет дело скорее с мортоновским "растворением субъекта» и погружением в городской хинтерланд. Ночной город непохож на дневной - банальность, но соприкосновение с городом в пространстве афотического вызывает к жизни опыт другого типа, не являющийся опытом очищения и отражения. Субъект буквально перестает быть наблюдателем и становится частью городского бессознательного, тенью среди теней, не пытаясь бороться с неустойчивой реальностью города, больше не скрываемой порядком света, а совпадая с ней.

Герои Хулио Кортасара переживают в ночном Париже утрату агентности - сама городская материальность начинает направлять их шаги (этому посвящена статья Алены Еременко в данном номере). Диккенс обсессивно блуждает по ночному Лондону, постепенно теряя способность отличать сон от яви. Маркер сдвига, когда субъект осознает себя частью гиперобъекта, - интеллектуальная операция, которой требует Мортон от своих читателей, когда говорит, что само человечество как биологический вид является агентом антропоцена, а вовсе не отдельный рациональный сознающий индивид. В ночном городе эта интеллектуальная операция оказывается доступна феноменологически.

Получившийся результат закономерно не обладает характеристиками «научного»так как не выполнен в логике отражения. Хинтерланд по определению грязный, путаный, неупорядоченный и в конечном итоге опасный для классической западной рациональности объект, который последняя хочет вытеснить как можно дальше из своей повседневности, забыть и старательно не замечать. Проблема в том, что подобная рационализация жизни, поверхностное исключение из нее всего мифологического, напротив, провоцирует городское бессознательное творить фантазмы, чтобы объяснить ужас, обнаруживаемый 
горожанами в пространственных лакунах города, и тем самым его развеять. Городской миф - как ранее волшебная сказка инструмент взаимодействия с ужасом неопределенности, и только многослойность перспективы не позволяет сделать весь мир объяснимым, сохраняя риск геотравмы.

Городской хинтерланд состоит из инструментов конструирования реальностей. Эти инструменты - рутины, черные ящики, устройства записи. По сути то, из чего «сделан» город: из рутин (коммьюты, предписанные траектории движения, маршруты транспорта), черных ящиков (метро - типичный «черный ящик» перемещения, мы просто «проваливаемся» в другой слой реальности, чтобы выпрыгнуть в другой точке пространства, феноменологически это медленный телепорт) и устройств записи - дискурсивных инструментов описания города: сейчас это "третьи места», «общественные пространства» и т. п. Оказываясь в ночном городе, мы выпадаем из рутин, проваливаемся внутрь «черных ящиков», оказываемся вне зоны действия устройств записи (буквально: визуальность как основной канал восприятия отказывает или по крайней мере уходит на второй план).

И вот тут нас догоняет реальность города.

Вернемся к сюжету о Каине. Первый город строит преступник, обреченный вечно наблюдать за гибелью своих потомков - жителей городской среды, живущих вместе с нестабильностью. Жиль Делез и Феликс Гваттари в «Тысяче плато» [Делез, Гваттари, 2010, с. 205-215, 700-706] подобным образом характеризуют различение между потомками Авеля и потомками Каина, называя последних наследниками преступления и городской жизни.

«Знак Каина»-телесный и аффективный знак недр, пересекающий одновременно и рифленую землю оседлого пространства, и номадическую почву гладкого пространства, не останавливаясь ни на том, ни на другом [Делез, Гваттари, 2010, с. 700].

Знак Каина - знак дырчатого, перфорированного пространства, разоснованной почвы, который указывает на то, что структура города никогда не обходится без скрытых в ней дыр, темных зон, провалов. Город - это постоянное ожидание предательства, которое и выдает его реальность в качестве объекта.

\section{Источники}

Александер Дж., Куракин Д. (2012) Культурная травма и коллективная идентичность//Социологический журнал. № 3. С. 5-40.

Башляр Г. (2014) Поэтика пространства. М.: Ad Marginem.

Бергер П., Лукман Т. (1995) Социальное конструирование реальности. М.: Медиум.

Вахштайн В. (2014) Пересборка города: между языком и пространством//Социология власти. № 2. С. 9-38.

Вилейкис А. (2019) и целого мира мало: политическое темной экологии//Логос. № 5. С. 103116.

Вилейкис А. (2020) Никогда больше: как осмысление холокоста породило современный экологический дискурс//knife.media-Нож. Режим доступа: https://knife.media/club/eco-holocaust/ (дата обращения: 01.11.2021).

Вудард Б. (2016) Динамика слизи. Зарождение, мутация и ползучесть жизни. Пермь: Гиле Пресс.

Гребер д. (2015) Долг: первые 5000 лет истории. М.: Ad Marginem.

Делез Ж. (1998) Различие и повторение. Спб.: Петрополис .

Делез Ж., Гваттари Ф. (2010) Тысяча плато. Капитализм и шизофрения. М.: Астрель.

Зиммель Г. (2002) Большие города и духовная жизнь//Логос. № 3. С. 23-34.

Зиммель Г. (2003) Эссе о чужаке//Социальное пространство: Междисциплинарные исследования. М.: инион. С. 173-178.

Карстенс Дж., Ланд Н. (2019) Введение в гиперверие. Интервью//Логос. № 5. С. 255-264.

Кудряшов И. (2019) Болезненная мечта о Городе//Syg.ma. Режим доступа: https://syg.ma/@ insolarance-cult/boliezniennaia-miechta-o-gorodie (дата обращения: 01.11.2021).

Лефевр А. (2017) Производство пространства. M.: Strelka Press.

Ло д. (2015) После метода: беспорядок и социальная наука. М.: Издательство Института Гайдара .

Мортон Т. (2019) Род человеческий: солидарность с нечеловеческим сообществом//Логос. № 5. С. 57-70.

Мортон Т. (2019) Стать экологичным. М.: Ad Marginem.

Руденко Н. (2017) Архитектура гибридов: киборгианская экология и космополитика городской жизни//Социология власти. № 1. С. 41-58.

Фрейд 3. (1995) Жуткое//Художник и фантазирование. М.: Республика.

Фуко М. (2016) Лекции о Воле к знанию. С приложением «Знание Эдипа». СПб.: Наука.

Anand N., Gupta A., Appel H. (Eds.). (2018) The Promise of Infrastructure. Durham, N.C.: Duke University Press.

Berardi F. (2015) Heroes: Mass Murder and Suicide. London: Verso.

Woodard B. (2013) On an Ungrounded Earth: Towards a New Geophilosophy. Brooklyn, NY: Punctum Books. 


\section{THE CITY AS A HYPER-OBJECT.} INTRODUCTION

Alexander Vileykis, Founder of the Center for New Philosophy (CNPh, Moscow); Fellow at the Institute of Social Sciences and Humanities, Tyumen State University (UTMN); 23 Lenin str. Tyumen, 625003, Russian Federation.

E-mail: alexandro.vileykis@gmail.com

Polina Khanova, Assistant at the Department of Ontology and Theory of Knowledge, Faculty of Philosophy, Lomonosov Moscow State University (MSU); 27 bldg 4 Lomonosovsky ave., Moscow, 119991, Russian Federation.

E-mail: linakhanova@gmail.com

Abstract. This article offers a conceptual reinterpretation of "the city" through the concept of a hyper-object, created by Timothy Morton. Tracing the evolution of the relationship between the urban environment and residents, the authors propose perceiving the city as a stable external object in relation to its population, possessing the characteristics of a hyper-object. Such a perspective helps to explain why rural and urban residents' perceptions of the environment differ so much and how the breakdown of normal urban daily life is arranged, leading to the formation of new anxieties and fears. The starting point for the author's interpretation is a reading of the Judeo-Christian myth of Cain and Abel as a description of the transition from animal husbandry to agriculture and, consequently, the birth of the urban way of life. Beginning with different ways of interpreting the myth, the authors discover key differences between life in an urban environment and a rural way of life-lacunas of space excluded by the population to the hinterland of the plan. Such a multilayered perspective is exclusively characteristic of the urban way of life.

By examining patterns of perception, the researchers show how such changes in everyday life have resulted from living in the shadow of the city as a hyper-object, which is something more than a place of residence.

Keywords: city; urban everyday life; myth; everyday magic; mythological consciousness; John Law; Timothy Morton; situational knowledge; urban studies; urbanism; Anthropocene; hyperobject; dark ecology

Citation: Vileykis A., Khanova P. (2021) City-Hyperobject. Introduction. Urban Studies and Practices, vol. 6, no 4, pp. 7-16. (in Russian) DOI: https://doi.org/10.17323/ usp6420217-16

\section{References}

Aleksander Dzh., Kurakin D. (2012) Kul'turnaya travma i kollektivnaya identichnost' [Cultural Trauma and Collective Identity]. Sotsiologicheskii zhurnal [Sociological Journal], no 3, pp. 5-40. (in Russian)

Anand N., Gupta A., Appel H. (Eds.). (2018) The promise of infrastructure. Durham, N.C.: Duke University Press.

Bachelard G. (2014) Poetika prostranstva [Poetics of Space]. M.: Ad Marginem Press. (in Russian)
Berger P., Luckmann T. (1995) Sotsial'noe konstruirovanie real'nosti [The Social Construction of Reality]. M.: Medium. (in Russian)

Berardi F. (2015) Heroes: Mass murder and suicide. London: Verso.

Deleuze Zh. (1998) Razlichie i povtorenie [Difference and Repetition]. SPb.: Petropolis. (in Russian)

Deleuze Zh., Guattari F. (2010) Tysyacha plato. Kapitalizm i shizofreniya [A Thousand Plateaus: Capitalism and Schizophrenia]. M.: Astrel'. (in Russian)

Foucault M. (2016) Lektsii o Vole k znaniyu. S prilozheniem «Znanie Edipa» [Lectures on the Will to Know. With an appendix "Oedipal Knowledge"]. SPb.: Nauka.

Freud Z. (1995) Zhutkoe [Uncanny]. Khudozhnik i fantazirovanie [Artist and Imagining] M.: Respublika. (in Russian)

Graber D. (2015) Dolg: pervye 5000 let istorii [Debt: The First 5000 Years]. M.: Ad Marginem. (in Russian)

Karstens Dzh., Land N. (2019) Vvedenie V giperverie. Interv'yu [Introduction to Hyperstition. An Interview]. Logos, no 5, pp. 255-264. (in Russian)

Kudryashov I. (2019) Boleznennaya mechta o Gorode [A Painful Dream about the City]. Syg.ma. Available at: https://syg.ma/@insolarance-cult/boliezniennaia-miechta-o-gorodie (accessed 01 Nobember 2021). (in Russian)

Lefevr A. (2017) Proizvodstvo prostranstva [The Production of Space]. M.: Strelka Press. (in Russian)

Lo D. (2015) Posle metoda: besporyadok i sotsial'naya nauka [After Method: Mess in Social Science Research]. M.: Izdatel'stvo Instituta Gaidara [Moscow: The Gaidar Institute Publishing House]. (in Russian)

Morton T. (2019) Rod chelovecheskii: solidarnost' s nechelovecheskim soobshchestvom [Humankind: Solidarity with Non-Human People]. Logos, no 5, pp. 57-70. (in Russian)

Morton T. (2019) Stat' ekologichnym [Being Ecological]. M.: Ad Marginem. (in Russian)

Rudenko N. (2017) Arkhitektura gibridov: kiborgianskaya ekologiya i kosmopolitika gorodskoi zhizni [Hybrid Architecture: Cyborg Ecology and Cosmopolitics of Urban Life]. Sotsiologiya vlasti, no 1, pp. 41-58. (in Russian)

Simmel' G. (2002) Bol'shie goroda i dukhovnaya zhizn' [The Metropolis and Mental Life]. Logos, no 3, pp. 23-34. (in Russian)

Simmel' G. (2003) Esse o chuzhake [The Stranger]. Sotsial'noe prostranstvo: Mezhdistsiplinarnye issledovaniya [Social Space: Interdisciplinary Studies]. M. : INION, pp. 173-178. (in Russian)

Vakhshtain V. (2014) Peresborka goroda: mezhdu yazykom i prostranstvom [Reassembling the City: Between Language and Space]. Sotsiologiya vlasti [Sociology of Power], no 2, pp. 9-38. (in Russian)

Vileikis A. (2019) I tselogo mira malo: politicheskoe temnoi ekologii [The World Is Not 
Enough: A Political Dark Ecology]. Logos, no 5, pp. 103-116. (in Russian)

Vileikis A. (2020) Nikogda bol'she: kak osmyslenie kholokosta porodilo sovremennyi ekologicheskii diskurs [Never again: How the Understanding of the Holocaust Gave Rise to Modern Ecological Discourse]. knife.mediaNozh. Available at: https://knife.media/

club/eco-holocaust/ (accessed

01 November 2021). (in Russian)
Woodard B. (2013) On an ungrounded earth: Towards a new geophilosophy. Brooklyn, NY: Punctum Books.

Woodard B. (2016) Dinamika slizi. Zarozhdenie, mutatsiya i polzuchest' zhizni [Slime Dynamics: Birth, Mutation and Creep of Life]. Perm': Gile Press. (in Russian) 